\title{
Changes of Administrative Accountability In Russian Transitions
}

\section{Heusala, Anna-Liisa}

2014

Heusala , A-L 2014 , ' Changes of Administrative Accountability In Russian Transitions ' , Review of Central and East European Law , vol. 38 , no. 3-4/2013 , pp. 267-293 . < http://booksandjournals.brillonline.com/content/journals/10.1163/15730352-00000004 >

http://hdl.handle.net/10138/309043

unspecified

acceptedVersion

Downloaded from Helda, University of Helsinki institutional repository.

This is an electronic reprint of the original article.

This reprint may differ from the original in pagination and typographic detail.

Please cite the original version. 


\title{
Changes of Administrative Accountability in Russian Transitions"
}

\author{
Anna-Liisa Heusala \\ University of Helsinki
}

\begin{abstract}
This article discusses the dynamics of transitions and security in the development of administrative accountability in Russia. It considers both the legal and administrative culture in Russia on the basis of the formation of administrative accountability and challenges found in this process. During the three periods of Russian transitions under study administrative accountability has developed as a result of an attempt to institutionalize new ideals in an old administrative culture. The article shows that, during these transitions, uncertainties and unintended effects of administrative changes have intensified traditional security concerns that have exceeded other considerations in the implementation of reforms. As a result the institutionalization of new professional practices and ways of thinking has been diffuse and administrative accountability remains legalistic.
\end{abstract}

\section{Keywords}

Accountability, rule of law, Russian administration, security, transitions

\section{Introduction}

This article sets out to analyze Russian administrative accountability and its relation to the phenomenon of 'securitization' in three transitional periods; (1) the post-1864 tsarist reforms; (2) the revolutionary reforms from 1917 until the end of the 1930s; and finally (3) the current reforms which began in the perestroika period. Administrative accountability refers to the scope and content of decision-making rights and practices and ways thinking which are connected to these rights. The administrative ideologies ${ }^{1}$ of Russia's transitions ${ }^{2}$ have represented the formalization of myths about administrative accountability. The law has been the key instrument of state building which has been aimed at altering the social contract ${ }^{3}$ of administration. To effect changes in the administrative accountability Russian transitions have tended to institutionalize new legal and social values ${ }^{4}$ that have been built into the structural and procedural arrangements ${ }^{5}$ of the state.

\footnotetext{
This article was prepared under the auspices of The Finnish Centre of Excellence in Russian Studies: Choices of Russian Modernisation, a Centre of Excellence funded by the Academy of Finland.

1 Anna-Liisa Heusala, The Transitions of Local Administration Culture in Russia (Kikimora Publications, Saarijärvi, 2005), 26-27.

2 For an analysis of Russian reform periods, see, for instance, Valentin Kolomiitsev, Rossiia. Reformy, transformatsiia, modernizatsiia. Zametki politologa (zdatel'stvo "Librokom", Moscow, 2011); Vladimir Lantin and Vladimir Lapkin, Politicheskaia modernizatsiia Rossii: tsikly, osobennosti, zakonomernosti (Russkoe slovo, Moscow, 2007); S.V. Kuleshov, J.P. Sviridenko and A.A. Fedulin, Modernizatsiia Rossii (XIX-XX vv.). Sotsial'nye i politicheskie protsessy (Alfa-M/Infra-M, Moscow, 2007); and A.V. Obolonskii (ed.), "K novoi Rossiiskoi grazhdanskoi sluzbe. Trudnoe vremia reformirovaniia", in Gosudarstvennaia sluzhba. Kompleksnyi podkhod (Izdatel'stvo Delo, Moscow, 2009), 260. Obolonskii separates five reform periods in the current transition, all of which have essentially centered around the question of whether Russian administration has continued its previous administrative culture of serving state interests as interpreted by the political elite, or whether it has modernized itself to become a public administration that provides services to its clientèle.

3 Leigh E. Grosenick, "Governmental Ethics and Organizational Culture", in Terry L. Cooper (ed.), Handbook of Administrative Ethics, Public Administration and Public Policy (Marcel Dekker, New York, NY, 1994), 189.

4 Turo Virtanen, Public Servants and Political, Organizational and Governmental Culture (Helsingin yliopisto, Yleisen valtio-opin laitos, Helsinki, 1987), 4.

5 Anthony Giddens, The Constitution of Society (T.J. Press Ltd., Padstow, UK, 1984).
} 
The analysis reveals some of the structural and ideological choices made by the leadership in these transitions. It evaluates the effect of choices on changing the elements of the natural state which have characterized Russian government - both in the tsarist and socialist periods. Attention is paid to the key ideas of political ideology underpinning power and the decision-making autonomy of the civil service. In the "natural state" - as defined in 2006 by North, Barry and Weingast - the political system is dominated by a limited and authoritarian elite which is one of the primary actors in the economy. The central government uses limitations on the right to form organizations to generate economic rent, holding the elite of the state together and providing order. This limited-access order - characterizing the natural state-has four components: (1) control of violence through elite privileges; (2) limits of access to trade; (3) relatively strong protection of property rights for elites versus relatively weak protection for non-elites; and (4) restrictions on entry into (and exit from) economic, political, religious, educational, and military organizations. As a result of these conditions, the rule of law exists for the elite. ${ }^{6}$

The continuity of the natural state, thus, is linked with both decision-making rules and societal trust. Peters has classified societal cultures into three groups with regard to decision-making rules. The closest to the liberal-democratic ideal type is that which can be found in societies where officials have very limited (rationalist-deductive) personal discretion or where precedents guide decision making yet leave room for the use of discretion (pragmatic-empirical). Both of these types strongly emphasize the professional competence of officials. The third group includes cultures where administrative decision-making is generally assumed to be the result of personal bargaining and negotiation. Rules of the administration itself constitute a place from which to begin bargaining. ${ }^{7}$ This type of 'flexibility' can be seen as typical for societies characterized by limited-access orders, ${ }^{8}$ where politics and economic gains are intimately intertwined. In a limited access order, trust is typically personal and not institutional, creating more opportunities for open corruption with impunity. ${ }^{9}$ All Russian administrative transitions have addressed the characteristics related to the limited-access order and negotiation practices in state administration decision-making. In post-1993 Russia, changes of the state administration have included attempts to set new standards for the implementation of decision-making rules in all three levels of government (federal, regional and local). These new standards refer to the ideals of the rule of law which include legality (e.g., hierarchy of rules), reliability and predictability, equality and objectivity, expediency (boundaries of discretion) and relativity (e.g., the necessity for a decision or action). In both international practices and Russian attempts to modernize its state administration the effects of the rule of law are meant to extend to the way in which the administration itself is organized. ${ }^{10}$ Horizontal cooperation and transparency among different public organizations in a state based on the rule of law is a by-product of trust in laws. Strengthening of transparency in the Russian administration through new standards for good governance is meant to enhance both political responsiveness and, particularly in the past decade, economic efficiency. ${ }^{11}$ The central challenge of this transition has been to sustain political stability without compromising these transitional goals.

6 Douglas C. North, John J. Barry, and Barry R. Weingast, “A Conceptual Framework for Interpreting Recorded Human History", Working Paper 12795, National Bureau of Economic Research (2006), available at 〈http://www.nber.org/papers/w12795〉, 14, 16, 17, 35. The authors built their theory on European economic history without considering the case of the Soviet Union. Thus, they see that few natural states have possessed a monopoly on the use of violence. In their view, control of the military is not consolidated in a natural state but is unevenly distributed throughout the dominant coalition.

B. Guy Peters, The Politics of Bureaucracy (Longman, New York, NY, 1984), 41.

North, Barry, and Weingast, op.cit. note 6 . A "limited-access order" implies a way of social life where privileges, divisions between the elite and other members of society, and patronage relations are important.

Heusala, op.cit. note 1, 26-27.

Camilla Stivers, "Citizenship Ethics in Public Administration", in Cooper, op.cit. note 3, 444-446.

Ibid., 37, 39. An "open-access order" can be seen to reflect the values represented in the liberal-democratic ideal type. An example of the administrative goals of this ideal type are the European good-governance principles that have been discussed in Sigma Papers No.27, "European Principles for Public Administration", CCNM/SIGMA/PUMA (99) 44/REV1 (1999), 9. Also in Jocelyne Bourgon, ”The history and future of nation-building? Building capacity for public results", 76(2) International Review of Administrative Sciences (2010), 197-218, the author defines modern accountability in the following manner: "Expanding the concept of accountability from that of process accountability for the exercise of powers by office holders to public accountability for progress towards system-wide and societal results." The complexities of putting good governance principles into action have been widely researched by various disciplines. The following scholars offer examples of this. Demetrios Argyriades, "Good governance, professionalism, ethics and responsibility”, 72 International Review of Administrative Sciences (2006), 155-170. In his conclusions of global public sector reforms, 
The three transitional periods which have been the objects of this study have changed the traditional relationship between civil-service practices and structures. Since 1991 the Russian state civil service has again gone through several rounds of reforms during which its structures, tasks, professional standards and the impact of Soviet administrative legacy on change have received attention. ${ }^{12}$ Currently, the Russian civil service is the object of massive educational programs, while structural reforms are establishing new organizations and reorganizing existing ones, as well as re-dividing authority of the state. The global paradigmatic turn of the 1980s in public-sector management has been visible in Russian administrative reforms since the beginning of the 1990s - particularly during the so-called 'privatization period' in 1995-1996. ${ }^{13}$ This turn has shifted the focus from traditional public-sector qualities to more result-based accountability also in Russia. ${ }^{14}$ Similar to the challenges found in the institutionalization of the rule-of-law principle, the creation of more result-based accountability in Russia has been marked by various degrees of success. Russian public administration has continued to arouse a great deal of criticism, which sees its institutional development as a failure of political democratization and true economic liberalization. According to critical views, the current Russian public administration has recycled many institutional characteristics of the informal Soviet administrative culture. Corruption, in particular, has received a great deal of attention as a risk to institutional trust and capacity building. ${ }^{15}$ For the past decade-plus, studies have discussed the meaning of political centralization and elite formations (particularly interwoven business and administrative elites) as reasons for administrative stagnation in Russia. In many reviews of the Russian state development, it is pessimistically suggested that these features connected to the previously described natural state make Russian public sector leaders too weak to effect any real change. ${ }^{16}$ Dysfunctional features of Russian administration in the post-perestroika period are often attributed to cultural legacies ${ }^{17}$ - seen as creating organizational path dependencies that define the future.

the writer argues for the strengthening of professional autonomy as the basis for ethical conduct. Mlada Bukovansky, "The Hollowness of Anti-corruption Discourse", 13 (2) Review of International Political Economy (2006), 181-209. The writer analyzes how the corruption issue has a position as one of the central problems facing transition economies and the developing world. In her conclusions, she states argues the following: "Rather than assume that the ends of modernity can be gracefully bequeathed to the developing world and transition economies of the former communist countries via the extension of a global market economy, the anti-corruption discourse would benefit from an injection of alternative modes of deliberating about what corruption actually means, and what needs to be done to engage leaders and citizens in deliberation about the substance of the public good, and the pursuit of collective ends."

12 Obolonskii, op.cit, note 2

13 Pavel Romanov, "Quality Evaluation in Social Services: Challenges for New Public Management in Russia", in Guy F. Peters (ed.), Mixes, Matches, and Mistakes: New Public Management in Russia and the Former Soviet Republics. (Local Government and Public Service Reform Initiative, Open Society Institute, Budapest, 2008), 9-53; and Vladimir N. Brovkin, "Corruption in the [sic] 20th Century Russia”, 40(2-3) Crime, Law \& Social Change (2003), 195-230.

14 The paradigmatic shift from traditional public administration to new managerialism in the public sector is described in Peter Aucoin, "Administrative Reform in Public Management: Paradigms, Principles, Paradoxes and Pendelums", 3(2) Governance: An International Journal of Policy and Administration (1990), 115-137; and Christopher Hood, "The "New Public Management" in the 1980s: Variations on the Theme", 20 (2/3) Accounting, Organizations and the Society (1995), 93-109. The traditional public sector paradigm put emphasis on two basic principles. Firstly, the public administration was clearly separate from the private sector in terms of continuity, purpose, practices, organization, personnel, compensations and career paths. The ideal type administration was a kind of "Jesuit corps of ascetic zealots". Secondly, the public administration served as protection against political and managerial discretion through its elaborate decision-making rules and structures. Legalism was intended to prevent unethical favoritism and corruption, and keep a distance between civil servants, politicians and different interest groups.

15 See, for instance, Vladimir Gel'man, "Subversive Institutions, Informal Governance, and Contemporary Russian Politics", 45(3/4) Communist and Post-Communist Studies (2012), 295-303; Alena Ledeneva, "Leadership and Corruption in Russia 2000-2004", Working Paper No.54, Centre for the Study of Economic and Social Change in Europe, University College London (2005); Barabashev and Straussman, op.cit.; Richard Rose and William Mishler, "Experience Versus Perception of Corruption: Russia as a Test Case", 11(2), Global Crime (2010), 145-163; and Yakov Gilinskiy, "Crime in Contemporary Russia”, 3(3), European Journal of Criminology (2006), 259-292; and Vladimir Shlapentokh, "Trust in public institutions in Russia: The lowest in the world", 39(2) Communist and PostCommunist Studies (2006) 153-174.

16 See, for instance, Valeri Ledyaev, "Domination, Power and Authority in Russia. Basic Characteristics and Forms", in Anton Oleinik (ed.), Reforming the State without Changing the Model of Power? On Administrative Reforms in Post-Socialist Countries (Routledge, London, 2009), 18-37; Anton Oleinik, "Introduction: Putting Administrative Reforms in a Broader Context of Power", id., 1-17; and Alexei Barabashev and Jeffrey D. Straussman, Russian Civil Service and Its Reform in Comparative Perspective (draft paper, prepared for the 8th Public Management Research Conference, School of Policy, Planning, and Development, University of Southern California, Los Angeles, CA, 29 September-1 October 2005) available at <http://pmranet.org/conferences/USC2005/USC2005papers/pmra.barabashev.straussman.2005.doc〉.

17 See Jan-Hinrik Meyer-Sahling, "Varieties of Legacies: A Critical Review of Legacy Explanations of Public Administration Reform in East Central Europe", 75 International Review of Administrative Sciences (2009), 509-528; and Gel'man, ibid. The meaning of the general communist legacy is being questioned as the dominant element in today's transitions. Offering a different approach, MeyerSahling suggests that it is important to distinguish carefully among different types of communist legacies, as well as the pre-communist and early-post-communist legacies. In addition, he would like to see researchers specify causal mechanisms that connect the past and outcomes of today's reforms. Vladimir Gel'man has assessed the effect that cultural determinism may have on the understanding of 
In this article, the author will attempt to shed light on the dynamics of historical processes that have contributed to administrative practices. These dynamics are seen as results of both the cultural legacies of past Russian administrations and choices made by agents who are constrained by their historical circumstances. The historical view has been motivated by the need to offer a conceptual bridge for understanding the connections between legal, security and organizational factors in the evolution of Russian state administration. To understand Russian administrative accountability and the difficulties found in its development, this article will introduce the concept of 'securitization'. It describes a situation where security concerns have started to counterbalance Russian administrative reform goals, with 'security concerns' referring to serious institutional risks that compromise public trust in government and make guidance of administrative decision-making difficult. As a result of these risks, the Russian leadership has relied on traditional bureaucraticcontrol methods to reduce ambiguity in its administrative goals and to strengthen its control over decision-making. The law has had a central meaning in the formulations and implementation of 'securitization'. The intensity with which the control methods associated with 'securitization' have been used has varied in Russian history. The analysis helps to understand why the core of Russian administrative accountability has remained as a combination of compliance toward rules and hierarchies in the recurring 'securitization' of legal and organizational goals.

\section{Accountability and the Reforms of the Autocratic Bureaucracy}

The mid-nineteenth century reforms of Russian legal institutions and local government were preceded by discussions on the suitable forms of reforming the state administration and its civil service. Russian state administration was viewed as both needing a better educated civil service and lacking in efficiently centralized decision-making. The regional (gubernskii and uyezdnii) levels which had been delegated the responsibility to act on behalf of the center, were criticized by government officials for failing to use their position effectively. Instead, criticism pointed out that the lower levels of Russian state administration hid themselves behind orders from higher levels of the administration. Lack of coordination between different ministries, as well as between the center and lower levels of administration was also a concern. ${ }^{18}$ These matters were complicated by fact that the law as a modern system of official norms and institutions, law as academic discipline and lawyers as professional specialists only appeared in Russia after the reforms of mid-nineteenth century. ${ }^{19}$ Most Russian people had lived under local customary law, where decisions were made by village elders, landlords, and the local aristocracy. National law included rule-based decisions and statutes that were often unpublished and contradictory. There was no national court system, and judicial functions were often adjuncts to administrative functions. Judges could be former soldiers or administrators who had no formal legal training. ${ }^{20}$

Prior to the nineteenth-century reforms, Russia's legal norms prohibited any civil servant (sluga) from using discretionary power. One reason for this was the lack of formal education among officials. Laws and regulations were used as substitutes for professionalization among administrative personnel, who were the personal representatives of the Emperor. ${ }^{21}$ Weissman has argued that lowerranking officials were dependent upon their supervisors, and that the social order emphasized the utmost servility to those of higher rank or social standing. Hence, the administrative culture was marked by a lack of speed, delays, and corruption, the first two of which were explained by the fact

subversive institutions. He contends that cultural and historical 'legacy' as an argument cannot explain varieties of subversive 'informality' or its dynamics.

18 L.E.Shepelev, "Tsinovnii mir Rossii, XVII- natchalo XX v.",(Izdatel'stvo Iskusstvo, Saint Petersburg, 1999), 87, 178, By mid-nineteenth century the yearly need for new civil servants with higher education was estimated to be about 3000 persons while the educational institutions at that time prepared around 400 graduates each year.

19 Teodor Taranovskii, "Sudebnaia reforma i razvitie politicheskoi kul'tury tsarskoi Rossii”, in L.G. Zakharova, Ben Eklof and John Bushnell (eds.), Velikie reformy v Rossii 1856-1879 (Moscow University Press, Moscow, 1992), 301-302.

20 Brian Levin-Stankevich, "The Transfer of Legal Technology and Culture: Law Professionals in Tsarist Russia”, in Harley Balzer (ed.), Russia's Missing Middle Class: The Professions in Russian History (M.E. Sharpe Inc., Armonk, NY, 1996), 224.

21 Taranovskii, op.cit. note 19, 303-304. 
that, in decision making, the smallest daily issue required approval from the center. ${ }^{22}$ Corrupt practices were a form of mediation by the social system in the rigid decision-making culture. Yaney has concluded that bribery was not only a form of submission but, also, a method of negotiation and self-assertion in which a subordinate could make use of a superior's power. In the absence of legal rules on which to depend for behavior, bribery was a harmonizing and stabilizing factor that resulted in expected administrative outcomes. ${ }^{23}$ Paradoxically the Russian state administration became powerful partly because of the powers of the autocrat had no clear legal limits ${ }^{24}$ and control of the state's administrative decision-making though legal means did not exist.

In spite of the structural weaknesses of administrative and legal decision-making before the mid $19^{\text {th }}$ century reforms, the meaning of the law became a growingly important component in the development of Russian state administration in the latter part of the $19^{\text {th }}$ century. ${ }^{25}$ The legal and administrative reforms of the mid-nineteenth century should be seen as an important attempt to professionalize the administration without challenging the autocratic order. The legislative reformers of 1864 believed that ideas of law and legality had a specified independent role and should not simply be a means to exercise the will of the sovereign. The reformists' intention was to limit the power of central government officials and share state power with lower level zemstvo and municipal government decision-makers. ${ }^{26}$ To effect these changes, in the 1864 reforms administrative ideology was revised to include the concepts of open public discussion (glasnost'), legality (zakonnost'), decentralization, and self-government (samoupravlenie). ${ }^{27}$ The goal for the introduction of these concepts was the modernization of Russian administrative thinking. ${ }^{28}$

Wortman has assessed the nineteenth-century reform of the Russian judicial system as the most successful part of this post 1864 reform process of systematization and professionalization. ${ }^{29}$ The major structural change in the legal system occurred when the judiciary was reformed in 1865-1866, including the establishment of a hierarchy of courts. Judges who were appointed by the Ministry of Justice were required to have legal qualifications, were paid salaries, and were given tenure for life. ${ }^{30}$ Appellation (kassatsiia) was one of the most successful formally institutionalized practices, although private individuals only had limited rights to request compensation on the basis of damage inflicted upon them by a decision of a state official. ${ }^{31}$ In fact, Wortman concludes that individuals were left without recourse in the case of official abuses and oversights. ${ }^{32}$ Administrative law did not offer protection from the sovereign's discretionary edicts and decrees. Its main purpose was to ensure compliance, not to protect the rights of individuals. The law was primarily coercive (prinuditel'noe pravo). The main legal instrument was the $u k a z$ (edict), a decree from the sovereign that maintained

22 Neil B. Weissman, Reform in Tsarist Russia, the State Bureaucracy and Local Government, 1900-1914 (Rutgers University Press, New Brunswick, NJ, 1981), 23-24, 26.

23 George L. Yaney, Social Evolution in the Domestic Administration of Imperial Russia, 1711-1905 (University of Illinois Press, Urbana, IL, 1973), 26.

24 Heusala, op.cit. note 1, 73.

25 Jane Burbank, "Legal Culture, Citizenship, and Peasant Jurisprudence: Perspectives from the Early Twentieth Century", in Peter H. Solomon Jr. (ed.), Reforming Justice in Russia 1864-1996: Culture and Limits of Legal Order (M.E. Sharpe, New York, NY, 1997), 2 82, 85. See also N. Algra, "The Earliest Law of Russia and its Sources", in Ferdinand, J.M. Feldbrugge (ed.), The Law's Beginnings (Brill, Martinus Nijhoff Publishers, Leiden, 2003), 93-113. In George L. Yaney, "Law, Society and the Domestic Regime in Russia, In Historical Perspective", 59 (2) The American Political Science Review (1965), 379-390, the author critically argues that "In Russia, on the other hand, the groups that responded to the state's growing efforts to maintain itself did not engage in much interaction with each other before the late nineteenth century. Up to the 1860 s, society in cities and villages alike was still strongly hierarchical at all levels, and the interests of the various "families"-the hierarchies of personal influence were still confined largely to maintaining their established local positions. [..] The social conflicts that plagued the Russian state were therefore qualitatively different from those that produced the Western legal systems. Conscious interests did not produce new legal relationships that would lend stability to society, but only a perpetual struggle between "families" whose heads were in favor and those whose heads were being shunted aside."

Taranovskii, op.cit. note 19, 308, 310, 312 .

Thomas Pearson, Russian Officialdom in Crisis: Autocracy and Local Self-Government 1861-1900 (Press Syndicate of the University of Cambridge, New York, NY, 1988).

Yaney, op.cit. note 23, 239.

Richard Wortman, "Russian Monarchy and the Rule of Law, New Considerations of the Court Reform of 1864", 3(1) Kritika: Explorations in Russian and Eurasian History (2005), 153.

30 Bill Bowring, "Politics, the Rule of Law and the Judiciary", in Neil Robinson (ed.), Institutions and Political Change in Russia (MacMillan and St. Martin's Press, Basingstoke and New York, NY, 2000).

Taranovskii, op.cit. note 19, 306 .

Wortman, op.cit. note 29, 168. 
This article has been published in Review of Central and East European Law 38 (2013) 267-293

public order, as did other administrative decisions (polozhenie estestvennogo prava). Edicts (ukaz) served as the main legal method for controlling the administration. ${ }^{33}$

The meaning of the nineteenth-century reforms was altered by the decision-making procedures that underpinned the autocratic nature of the state. ${ }^{34}$ The hierarchy of laws in the Imperial Russian state did not support a transition toward impersonal trust. The rulings of the State Council, which were confirmed by the Tsar, should have been the foremost source of authority and taken precedence over other decisions. A minister's order should have been approved by the Council. In fact, the Tsar decided whether ministers made laws without the consultation of the Council. Orders by the Tsar had the force of law, even in cases when they contradicted existing legislation. Neither administrative officials nor judges in courts had the right to pass judgment on the validity and judicial strength of Tsar-approved laws. Yaney has concluded that legal acts of the state in the $19^{\text {th }}$ century were typically temporary, regionally or organizationally targeted instructions which obstructed the development of a coherent legal system. This system both mirrored the social realities of decision-making inside the state administration and contributed to its recycling. The officials at all levels of government often bypassed regulations and instead used personal networks to get their work done. Personal relations offered the best protection for Russian citizens against arbitrary decisions by those in higher positions, and for the lower level civil servants against their supervisors. ${ }^{35}$

The tension between a European-type modernization which stressed professionalism and an autocratic culture which underlined social order resulted in the counter-reform of Alexander III (1881-1894), who demanded that civil servants unite against the changing society. Security concerns, as they were defined by the Tsar, resulted in harsh control methods which involved the police and the prosecutors. The reorganized police were used by the Interior Ministry to direct political control and counterrevolutionary work through the local security police. ${ }^{36}$ Writing in 1997 , Kazantsev concluded that the prosecutors treated the law from the viewpoint of a struggle against unwanted political elements, whereas effective supervision of the administration was secondary. The idea that guidance from the administration would have resulted in growing legality did not materialize. Instead, dysfunction arising from unprofessional behavior continued. ${ }^{37}$

Thus, legal protection of the population and a more general idea of service were only beginning to emerge as concepts of administrative work. This only was changed, at least formally, by the 1906 Constitution $^{38}$ : it defined civil rights and provided a basis for legal protection against arbitrary administrative acts; political rights and the right to form organizations were established to a limited degree; freedom of speech and religious freedom were guaranteed. ${ }^{39}$ However, the limits of these changes became clear in the codification of new laws in the context of existing legislation. ${ }^{40}$ Difficulties in the implementation of the various reform policies reflected in the laws caused additional problems in terms of accountability. Yaney has stated that many of the statutes in Russian law from 1711 to 1905 were not enforceable legal rules but, rather, exhortations to behave or work

Taranovskii, op.cit. note 19, 302-303.

Heusala, op.cit. note 1, 108. Yaney, op.cit, note 25, 384. The writer states that "No Russian ruler (in Russian history) has ever willingly considered the outright surrender of state power to institutions apart from the central government's executive organization." He argues that the legal and local administration reforms of the $19^{\text {th }}$ century were not primarily a question of "freedom" but a question of more efficient government.

Yaney, op.cit. note 23, 261, 264. Yaney, op.cit., note 25, 385-386

36 Michael Florinsky, Russia: A Short History (McMillan, London, 1969); Sergei Pushkarev, Samoupravlenie i svoboda v Rossii (PossevVerlag, V. Gorachek KG, Frankfurt am Main, 1985); and P.I. Shlemin and V.I. Fadeev (eds.), Mestnoe samoupravlenie. Rossiiskii variant (RAN, Institut nauchnoi informatsii po obshchestvennym naukam, Moscow, 1993). In 1881 the security police 'Ohrana' was organized to safeguard public security and order.

Sergei M. Kazantsev, "The Judicial Reform of 1864 and the Procuracy in Russia”, in Solomon, op.cit. note 25, 44-60.

“Osnovnye gosudarstvennye zakony” (23 April 1906), Polnoe Sobranie Zakonov Rossiiskoi Imperii (1881-1913), 3rd series Vol.XXVI item 27805. An English translation is available at <http:// www.dur.ac.uk/a.k.harrington/fundlaws.html>.

Op.cit. note 27 , article II

Tatiana Iu. Borisova, “Zakon i zakonnost' v russkom kodekse 1906-1917”, 1 Istochnik, istorik, istorii. Sbornik nauchnikh rabot (2001), $11-41$. 
This article has been published in Review of Central and East European Law 38 (2013) 267-293

according to various ideals. ${ }^{41}$ In this regard, the administrative and legal reforms which started in 1864 and that could have, in time, strengthened administrative accountability remained uncompleted.

To summarize, it can be said that the structural foundations for a statewide legal system were instituted at a formal level in the latter part of the nineteenth century. In spite of the changes on the legal front, the Russian state administration, however, resembled a limited-access order. Administrative accountability remained absent and the protection of rights arbitrary. Institutional trust or horizontal cooperation did not develop to effect real modernization. Instead, patronage relations formed an unofficial hierarchy inside the administration, where corrupt practices continued to undermine professional behavior and written laws. But since 'securitization' meant that attention to (perceived) political risks to the autocracy were given priority over other considerations, such as the quality of administrative work; corrupt practices were not seen as a dysfunction of the autocratic culture of the nineteenth century but, rather, as an essential component in its continuity.

\section{Accountability in the Revolutionary Soviet Administration}

Administrative accountability within the mature Soviet administration had its roots in the postrevolutionary era of the 1920s and 1930s. During this period, the fundamentals of administrative and legal logic were institutionalized in the Soviet economic system. The 1917 October Revolution had three basic purposes that provided the basis for administrative change. The first of these was the relationship between state and citizen. The great rupture was Lenin's focus on the idea of the state as the representative of all society, ${ }^{42}$ which had to be reflected in its formal decision-making structures. Because, at the time of the revolution, Russian society did not correspond with the class structure of a socialist state, one of the central tasks of revolutionary change became the neutralization of the middle class by the dictatorship of the proletariat. This constituted the second purpose. A centrally led economy was the third purpose and the organizational goal of the transition.

Administratively, these three purposes resulted in two developments. The first was the active enforcement of the dictatorship of the proletariat, under which administration and law were used as instruments for education and for elimination of the opposition. The second was industrialization by changing legal principles and introducing organizational models that stressed oversight, new accountability, and discipline ${ }^{43}$ The transition was meant to change the elite structure by accepting new layers of society into it and by including the whole population in the system of economic benefits. As the revolution progressed, the goals of a new administrative efficiency were sacrificed for security concerns that emphasized political control. It soon became clear that the hierarchical and non-democratic relations between the elite and non-elites which had characterized the Imperial era continued in the new socialist Russia.

In a revolutionary state, administration was a means for uniting different parts of the new society where citizens had no autonomous value ${ }^{44}$ beyond their membership in a collective. Lenin wrote about the re-education of society through an 'elastic organization' that initially replaced both capitalist law in general and contracts in particular to manage the transition to socialism. Above all, elasticity meant disciplinary action that could and should be forced upon people in the form of a dictatorship. Crushing opposition was necessary to enforce the new system's superiority in terms of knowledge, wealth, and organization. Confusion, shifting positions, and uncertainty were the natural results of the transition. In this environment, ideological and practical control was to be implemented through the courts, which Lenin saw as a medium for public education of obedience. ${ }^{45}$

\footnotetext{
Yaney, op.cit. note 23, 21.

Vladimir I. Lenin, Kootut teokset neljässä osassa (Kustannusliike Edistys, Moskova, 1968, translated from Izbrannye proizvedeniia v 4tomah, Politizdat, Moscow, 1968), 154

Heusala, op.cit. note 1 .

Ibid., 119 .

Lenin, op.cit. note 38, 455-457.
} 
This article has been published in Review of Central and East European Law 38 (2013) 267-293

Structural changes reflected the search for a balance between new legal ideals and organizational stability for the growth of a socialist economy. The initial changes were abrupt and soon created new risks. A 1917 decree proclaimed the end of the courts, prosecutors, and the advocacy, and installed a new way of organizing the system of revolutionary justice. ${ }^{46}$ The first years of this experiment saw old laws and revolutionary lawyers co-existing with new decrees and institutions. Legal nihilism ${ }^{47}$ led to the factual breakdown of the legal system; the courts were made subordinate to administrative party organs and many questions continued to be decided outside the court system. By 1922, the statute "On the Judicial System" 48 instituted new socialist courts (the same year in which new RFSRS civil and criminal codes were promulgate). The new people's judges were elected and could be dismissed by the local authorities. ${ }^{49}$ Questions of economic security, political 'education' and battles over decision making at the local level merged in the work of the three-institution collective (the so-called "troikas") by the end of the 1930s. In the purges, this collective-comprising the first secretary of the Party committee; the head of the state security organ, the NKVD; and the prosecutor's office - was used to enact rulings, including capital punishment. ${ }^{50}$ As the political supervisor of legality in the Soviet administrative organizations throughout the country, the troikas took part in purely organizational matters, such as advising factories about production or farms about the grain harvest. ${ }^{51}$

Under new Soviet leadership, legal relativism was equated with the principle of dialecticism. This meant looking at practical choices in terms of the conditions set by time and place. For the central government, one such condition was the rampant corruption at the local level which became an important security risk. The connection between these political risks in rural Russia ${ }^{52}$ and the theoretical and practical formulations of Soviet law in the 1920s can be drawn from Stalin's July 1928 writing of the so-called "special measures". ${ }^{53}$ These had been applied to forcibly collect grain from the countryside. Stalin's conclusion was that special measures could and should be used when there were no other useful means to direct the markets. ${ }^{54}$ Security concerns, therefore, led to the introduction of severe control methods, one side-effect of which was the elimination of independent communications in Soviet decision making. Orders both shaped the new ideology and instituted the Party as the primary medium for the communication of orders by the leadership to the people. Ideologically, Marxism was institutionalized as a 'religious' source of administration, and its interpretation was controlled by the Party elite. Under the Stalinist regime, in particular, ideology was interpreted in such a vague and inexact manner that it could be used to legitimize virtually any political decision. ${ }^{55}$

46 Bowring, op.cit. note 26. The first Dekret "O Sude" (22 November/5 December 1917), Sobranie Uzakonenii (SU) RSFSR (1917) No.4 item 50, is reproduced at <http://constitution.garant.ru/history/act1600-1918/5312/>. There would be two more such decrees in February and July 1918.

47 Eugene Huskey, "From Legal Nihilism to Pravovoe Gosudarstvo", in Donald D. Barry (ed.), Toward the "Rule of Law" in Russia? Political and Legal Reform in the Transition Period (M.E. Sharpe, New York, NY, 1992), $23-42$.

$48 \quad$ Polozhenie "O sudoustroistve RSFSR 1922 g." (11 November 1922) SU RSFSR (1922) No.69 item 902.

49 Bowring, op.cit. note 26, 72.

50 Aleksandr Sungurov, Funktsii politicheskoi sistemy: ot zastoia k postperestroike (Sankt-Petersburgskii gumanitarnyi i politologicheskii tsentr "Strategiia", St. Petersburg, 1998), 73.

51 Gordon B. Smith, "The Struggle over the Procuracy", in Solomon (ed.), op.cit. note 17, 350; and Peter H. Solomon, Soviet Criminal Justice Under Stalin (Cambridge University Press, New York, NY, 1996), 231.

52 Brovkin, op.cit., note 13, 206-207. Brovkin states that by the mid-1920s, the accumulation of wealth through private agriculture led to political consequences in rural elections. The well-to-do peasants bribed local officials, co-opted poorer peasants, and tried to effect changes in the local soviets. In 1926, a new electoral law expanded the category of kulaks and traders who were deprived of voting rights. By 1928, however, the culture of corruption had continued to worsen, and local officials considered their position as a source of revenue for themselves. Brovkin bases his assessment on regional Party and security reports from the period.

Spetsial'nye mery.

Josef V. Stalin, Teokset, 11 osa, 1928-maaliskuи 1929 (Karjalais-suomalaisen SNT: valtion kustannusliike, Karjalais-Suomalainen SNT: Ministerineuvoston Poligrafizdatin Sortavalan kirjapaino, Sortavala, 1951), 191-192.

55 Viktor P. Makarenko, Biurokratiia i stalinizm (Izdatel'stvo Rostovskogo universiteta, Rostov-on-Don, 1989), 239. Also, Brovkin has concluded that if Stalin had decided to proclaim himself the Emperor, there would not have been any opposition in the Communist Party on ideological grounds. The idea of building socialism degenerated into understanding that it meant fulfilling orders from above in terms of taxes, targets, plans, and construction sites. See Brovkin, op.cit. note 13 , 211, 
This article has been published in Review of Central and East European Law 38 (2013) 267-293

'Securitization' of the legislative work and management of organizational questions started to systematically dominate the new Soviet administrative culture in the 1920s. Writing in 1995, Korzhikhina has shown how legislative work connected with urgent administrative and political questions was used to achieve rapid industrialization, concentration of power and consolidation of the new administrative structures. Guidance included a collection of principles and methods of governance based on massive repression, which were both court-ordered and extralegal. Legislation that particularly encouraged arbitrary and repressive decision-making peaked in 1930-1932, during which time Party decisions were made concerning the collectivization and liquidation of farm owners. ${ }^{56}$ A decree on revolutionary legality was passed in $1932 .{ }^{57}$ The term 'enemy of the people' (vrag naroda) appeared, a development that culminated with the 1934 joint decree on terrorist acts. ${ }^{58}$ These developments were preceded by theoretical discussions on the role of law in a socialist society. The creation of socialist law was influenced by attempts to eliminate ambiguity in terms of political goals and give the Party broad discretion in its control of the administrative system. As the systematic modernization of public administration became the central part of the new economy, legal thinking was created to support decision-making in the planned economy. Rigby, in his 1979 opus, has noted that Lenin was very much concerned with precision, discipline and accountability. ${ }^{59}$ Yet, crafting the right approach to a new form of governance was not simple. Petr Stuchka, the first president of the RSFSR Supreme Court, considered in 1927 that communism specifically meant the victory of socialism over any law-not the establishment of some socialist version of the previous law. Ideologically, the abolition of classes essentially meant the death of the law. ${ }^{60}$ Stuchka's ideas were in line with those of Evgenii Pashukanis, who-as the architect of the first socialist theory of law - saw the idea of a social contract underlying a political order based on the supposed harmony of equal individuals. The law, by nature, is contractual and individual; this makes it impossible to talk about "proletarian law" ${ }^{61}$ Norms were not Pashukanis' primary concern; instead, factual economic relations in society were to form the basis of legal thinking. Therefore, norms could not be separated from the concrete level into an abstract set of rules. ${ }^{62}$ Pashukanis did not accept the use of former tsarist legal professionals to investigate whether something was permitted 'from a legal point of view' because matters of importance could only be decided on political grounds. The legal form of life and administrative (political) goals were inseparable. ${ }^{63}$

These interpretations had at least three consequences for administrative accountability. First, the possibility of external legal oversight over official decision-making was eliminated. Second, the law was turned into a means of ideological control. Third, citizens also had begun to use the administration, instead of courts, for dispute resolution. ${ }^{64}$ The role of the courts as independent sources of legal authority in society was limited by new socialist laws. As the revolution was bureaucratized, there could be no moral foundation for the law that would have been above the needs of the state as interpreted by the new elite. The legal profession served the same purpose. The judicial sector was made a branch of the party-guided administration. The position of lawyers changed from independent practitioners to 'judges' assistants'. This culture was extended to other

56 Tatiana P. Korzhikhina, Sovetskoe gosudarstvo i ego uchrezhdeniia, noiabr' 1917-dekabr' 1991 (Rossiiskii gosudarstvennyi gumanitarnyi universitet, Moscow, 1995). The author calls the produced legal documents "emergency legislation" (chrezvytsainoe zakonodatel'stvo) which characterizes most of all the style of legislative work and management of government affairs.

57 Bowring, op.cit. note 26, 72. Postanovlenie "O revoliutsionnoi zakonnosti” (25 June 1932), Sobranie Zakonov SSSR (1932) No.50 item 298; an earlier decree with the same title dates from November 1918: SU RSFSR (1918) No.90 item 908.

58 Postanovlenie TsiK i SNK SSSR “O vnesenii izmenenii v deistvuiushchie ugolovno-protsessual'nye kodeksy soiuznykh republik" (1 December 1934), Izvestiia (5 December 1934). See Korzhikhina, op.cit. note 51, 19-20. Inquiries into such crimes could not proceed for more than 10 days, hearings were conducted without the parties present, all rights of appeal and petitions for clemency were denied, and sentences were carried out immediately.

T.H. Rigby, Lenin's Government Sovnarkom 1917-1922 (Cambridge University Press, Cambridge, 1979), 23, 26.

Harold J. Berman, Justice in the USSR: An Interpretation of Soviet Law (Harvard University Press, Cambridge, MA, 1963), 26-29.

Ibid., 26-29.

Markku Kivinen, Valtion käsitteellisen tutkimisen ongelmista (Helsingin yliopisto, Helsinki, 1977), 6, 39.

Jevgenii Pashukanis, Valittuja teoksia yleisen oikeus- ja valtioteorian alalta (Kustannusliike Progres, Moskova, 1985, translated from Izbrannye proizvedeniia po obshchei teorii prava i obshchei teorii gosudarstva, Nauka, Moscow, 1980).

64 Anna-Maria Salmi, Social Networks and Everyday Practices in Russia (Kikimora Publications, Saarijärvi, FI, 2006), 23-24; and Huskey, op.cit. note 51, 24-25. 
This article has been published in Review of Central and East European Law 38 (2013) 267-293

purely administrative bodies that settled different types of disputes. ${ }^{65}$ The prosecutor's office became the heart of the legal system. Its authority was extended to political-organizational issues in a wide array of matters. ${ }^{66}$

Stalin's 1936 speech on the draft Constitution ${ }^{67}$ can be seen as the culmination of the legaladministrative transition. For Stalin, the Constitution was not a code of laws, meaning that it did not preclude routine legislative work on the part of the legislative bodies. ${ }^{68}$ The law was transitional; thus, no fixed legal standards could be used for assessing its future use. The Constitution was to be seen as a proclamation of changes that had already been achieved - not as a document enumerating the basic principles of society. ${ }^{69}$

The practical life of the Soviet administration started to resemble the features of the previous autocratic culture. This meant that guidance on new Soviet administrative decision-making was heavily dependent on different types of administrative and political regulations and decisions, further weakening the status of legislation. Workers in localities were educated by means of circulars (tsirkulary) giving them advice about the content of their work, its form and rituals. ${ }^{70}$

Economic planning and the role of the local-level administration became legally connected through property rights. In his 1963 work, Berman has shown that, formally, property rights existed to protect and direct the administration of property on behalf of the socialist economy. In this sense, administration was less than full ownership but more than just the giving of orders. ${ }^{71}$ More important for the citizen was the fact that the administration channeled positions that exercised control over the economy, which became a venue for receiving rights in society. ${ }^{72}$ The administrative practices connected to the planning system over time created an administrative culture in which according to Brovkin's 2003 analysis, everything, in theory, belonged to the state, but those individuals who managed it on the state's behalf were free to extract benefits for themselves. Because of this structural feature which roots were in the decisions of the revolutionary period, Soviet administrative culture became rampant with the trading of favors, the projection of authority, and influence peddling. Brovkin concludes pessimistically that one could abuse office for personal gain by showing obedience to the center and fulfilling orders. ${ }^{73}$

The Soviet administration of the 1920s and 1930s succeeded in modernizing its workforce in terms of education levels and the division of tasks based on expertise. In principle, this could have meant considerably stronger authority on the part of individual officials. However, the harsh concentration of power as a method of increasing control and raising awareness of state goals counterbalanced the modernization of the civil service during these above mentioned critical decades of the transition. A similar effect was created through the division of administrative work into specialized tasks coordinated by the Party. Security of the planning system, as understood by the Party, made the autonomy of individual officials weak and authority concerning the organization of work diffuse. Officials were implementers and not developers. The role of corruption and the political risks created by it were significant for the administrative 'securitization' of the Soviet system. The evolution of accountability was shaped by both the emphasis on legalistic decision-making and the circumvention of official structures in contacts with citizens.

\footnotetext{
65 John N. Hazard, Settling Disputes in Soviet Society: The Formative Years of Legal Institutions (Columbia University Press, New York, NY, 1960), 46.

Heusala, op.cit. note 1, 171 .

I.V. Stalin, "O proekte Konstitutsii Soiuza SSR: Doklad na Chrez'vychainom VIII Vsesoiuznom s"ezde Sovetov 25 noiabria 1936 goda”, in I.V. Stalin, Sochineniia (Izdatel'stvo Pisatel', Moscow, 1997), Vol.4, 199-147.

Ibid.

Heusala, op.cit. note 1,163 .

Korzhikhina, op.cit. note 51, 8, 24.

Berman, op.cit. note 55.

Heusala, op.cit. note 1. Also, Brovkin has painted a grim picture of the birth of corrupt practices and ways of thinking during the 1920s and particularly the period of the New Economic Policy, which united the urban Communist Party elite with private entrepreneurs. Problems arose when private companies had to deal with competing administrations that all expected their share. See Brovkin, op.cit. note 13, 204.

73 Brovkin, op.cit. note $13,213$.
} 
In this transition, the limited-access order of the tsarist bureaucracy was recycled. Legal protection of individual rights was turned into a question of receiving economic benefits from the Soviet economy. Class structure was changed but not abolished. Institutional trust was not a concern for guidance of the system, because the Party took the role of horizontal and hierarchical coordination and had a monopoly on official communication. Furthermore, members of the nomenklatura were in privileged positions to receive economically valuable inside information. Because of the intensive restriction on the free formation of organizations, administrative careers were often built on securing positions in the planning system for different types of rent-seeking.

\section{Administrative Accountability Since the Perestroika Period}

The policy of glasnost' during the perestroika period can be seen as an attempt to eradicate the rift between the real and normative cultures in the state's planning process. Melin has described the centralized five-year plan as a matter-of-fact law for production management. ${ }^{74}$ The reforms of the glasnost' period were aimed at giving the local level a chance to be heard in the planning process. ${ }^{75}$ Mikhail Gorbachev favored the diffusion of ideas through the transfer of best practices from other countries with liberal-democratic backgrounds. The concept of a 'socialist law-based state' aimed to achieve a social contract in which individual rights were respected and the Party administration was under legal control. ${ }^{76}$

The introduction of a socialist form of the rule of law collided with the realities of the nomenklatura culture and bureaucratic bargaining in the everyday administrative market. ${ }^{77}$ The avalanche of sublaws and organizational instructions dominated over federal laws in the daily execution of the plan. The idea that individual rights - including economic ones - would have to be considered over all other considerations was immature. From a purely structural point of view, this would have required a solid norm hierarchy that put state laws before local and organizational rules. ${ }^{78}$ A good example is the role of the prosecutor's office. Prosecutors worked to advance citizens' complaints against administrative action with regard to such matters as housing, pensions, and other social services. However, prosecutors had absolute discretion to either drop or pursue an investigation. A citizen's option to exercise his or her rights was retrospective. The Party's close involvement in providing policy guidance for prosecutors made citizens unwilling to be in open conflict with the Party. ${ }^{79}$ As Hammer has pointed out: "Soviet citizens [had] developed some sense that, if they obeyed the law, the law would leave them alone." 80

Writing in 1998, Sungurov has analyzed how the nomenklatura, which formed the administrative elite, was largely above the court system except for the most serious crimes. Judges and their tenure depended on Party nomination, and postings were only temporary. Candidates were nominated by the legal departments of the Soviet executive committees, which also oversaw the work of the courts. The Party's Department of Political Administration officially confirmed candidates for the judiciary. Good relations with the local executive and Party committees were a key to getting practical matters solved. ${ }^{81}$ This web of patronage resulted in what Ledeneva has called "telephone justice" (and has been called "telephone law" in many circle); i.e., the practice of making informal commands or requests or giving signals in order to influence formal procedures or decision-making;

\footnotetext{
74 Harri Melin, "In the Shadow of the Plan: Factory Management and the Problem of Social Transition", in Leo Granberg (ed.), Russia: The Snowbelt (Kikimora Publications, Saarijärvi, FI, 1998).

Christer Pursiainen, Venäjän idea, utopia ja missio (Ulkopoliittisen instituutin julkaisuja, Gaudeamus, Helsinki, 2001 ), 87.

Louise I. Shelley, "Legal Consciousness and the Pravovoe Gosudarstvo", in Barry, op.cit. note 43, 68.

Simon Kordonskii, Rynki vlasti: Administrativnye rynki SSSR i Rossii (OGI, Moscow, 2000). The administrative market refers to a situation where decisions about resources where made at different levels of the Soviet bargaining network. These networks were guided by unofficial negotiation rules and attempts to reach satisfactory compromises for all administrative parties. Unofficial linkages and mutual benefits were grounds for activity in what was a politically immobile situation.

Vladimir Entin, "Lawmaking Under Gorbachev Judged by the Standards of a Law-Based Society", in Barry, op.cit. note 43, 360.

Gordon B. Smith, Reforming the Russian Legal System (Cambridge University Press, Cambridge, 1996), 353.

Darrell P. Hammer, The USSR: The Politics of Oligarchy (Westview Press, Boulder, CO, 1986), 172.

Sungurov, op.cit. note 46, 75 .
} 
This article has been published in Review of Central and East European Law 38 (2013) 267-293

the predominance of oral commands over written instructions, self-censorship, the dominance of administration over the judiciary, and the use of legal institutions for extralegal purposes. ${ }^{82}$

At least to some degree, corruption in the Soviet time can be understood as a way of mediation in the rigid planning system. In his critical analysis, Brovkin states that:

"The priority of the Soviet management [in the planned economy] was not performance but concealing bad performance and extracting as much as possible from the state budget for their plant, [on the] one hand, and from their plant for themselves, on the other. The state wanted more production for less cost. The management wanted to reduce required targets [of the plan], increase state allocation and siphon off extra surplus." 83

The socialist production system meant that appointed managers trusted the state to help them. Brovkin sees the structure of Soviet industry as discouraging efficiency and encouraging double accounting and corruption. ${ }^{84}$ If the decision maker in this web of relations followed the accepted levels of informal behavior, ${ }^{85}$ in many ways s/he was free of personal accountability.

A major shift in all of this was to be seen in 1993: against background of nomenklatura decisionmaking and planned economy, the new Russian Constitution of $1993^{86}$ has established requirements for the creation of a whole new type of trust between citizens and the state. The formal creation of a tripartition of power under the new RF Constitution represents the most radical structural change in the ongoing transition. The transition and modernization discourses in the post-1993 era have both been based on the idea that the rule of law is essential to Russia's economic performance and reliability. ${ }^{87}$ One of the greatest challenges facing the social and legal sciences focusing on the Russian situation is to understand this change in a realistic time frame. In the past 10 years frustration over persistent problems in the post-1993 era has begun to overshadow understanding the complexities of major institutional change in Russia.

In terms of a cultural shift, the Russian administration has suffered from 'risk administration' features that have contributed to the recycling of elements of Soviet administrative culture. ${ }^{88}$ The regionalization period in the early $1990 \mathrm{~s}^{89}$ coincided with the urgent need for major legislative reforms and structural reorganization ${ }^{90}$ at all levels of society. President El'tsin set out to neutralize possible political opposition to the transition goals at the central level by delegating political and

\footnotetext{
Alena Ledeneva, "Telephone Justice in Russia”, 24(4) Post-Soviet Affairs (2008), 326.

Brovkin, op.cit. note 13 .

Ibid., 203.
}

The concept of risk administration is defined in detail in Heusala, op.cit. note 1, 45-48

The 1993 RF Constitution: Konstitutsiia Rossiiskoi Federatsii, Rossiiskaia Gazeta (25 December 1993). The tripartition of power refers to the formally established separation of legislative, executive and judicial powers of the state. This situation differs from the Soviet government in which all these powers were linked through the Party decision-making structures.

John K.M. Ohnesorge, "The Rule of Law”, 3 Annual Review of Law and Social Science (2007), 99-114.

88 The concept of 'risk administration' is defined in detail in Heusala, op.cit. note 1, 45-48. The concept builds on the theories of several scholars, most notably Ulrich Beck and Fred W. Riggs and includes the following elements: (1) hectic structural changes; (2) a quasimarket economy; (3) incoherent state structures; (4) formalistic laws, rules, and norms; (5) ineffective administrative guidance; (6) separate channels for exercising official and unofficial power and control; (7) a new type of ignorance (difficulty making choices and calculations); (8) politics inside the administration; (9) complicated client relations because of attempts to enforce the law; (10) cliques and nepotism; and (11) tolerance of a high degree of uncertainty. A risk administration is typical for limited-access orders and transitional societies, but its features can be found in all societies.

Soili Nystén-Haarala, Russian Law in Transition. Law and Institutional Change (Kikimora Publications, Helsinki, 2001).

90 Examples of major changes have been studied by Peter H. Solomon Jr., "Law in Public Administration: How Russia Differs", in Oleinik, Reforming the State Without Changing the Model of Power, op.cit. note 15, 125. Solomon has noted that the major legal reform achievement was the establishment of security of tenure for federal judges. Under the 1992 Law on Judges, a judge could be dismissed based on a decision of a Judicial Qualification Committee. Political networking to find suitable candidates for judges has moved to more neutral ground, at least officially. The new Constitutional Court is discussed by Pamela Jordan, "Russian Courts: Enforcing the Rule of Law?", in Valerie Sperling (ed.), Building the Russian State, Institutional Crisis and the Quest for Democratic Governance (Westview Press, Boulder, CO, 2000), 196, 198. Jordan describes how the 1994 Federal Law on the RF Constitutional Court made the new court a 19-member organ nominated by the Federation Council. The Court's task was to review legislative acts, including orders of the President, federal laws, republican constitutions, and treaties at both the national and subject levels. Individuals' appeals were accepted on the basis of an inquiry on the constitutionality of legislation dealing with a particular case from a court. 
This article has been published in Review of Central and East European Law 38 (2013) 267-293

economic power to the regions. The decisions made in the early 1990s regarding the dismantling of the system of central planning and subsequent privatization have generally been described as corrupt. ${ }^{91}$ Ledeneva has shown how the merger of state and market sectors in the so-called 'nomenklatura business' was an important development for strengthening corruption. Ledeneva has come to the conclusion that in the first part of the 1990s informal arrangements were made at the local and regional levels to either prevent or facilitate the bankruptcy of enterprises, or to intervene in the mechanisms of corporate governance. She states that while the macroeconomic level was showing promising signs in the 1990s, the microeconomic level used double bookkeeping, false reporting and bribery. ${ }^{92}$ As a consequence of the choices made in this period and particularly during the privatization of Russian state assets in 1995-1996, a multitude of transitional side effects and new risks have been created. The biggest risks were created in the breakdown of the Russian state's budgetary planning in the absence of a functioning and tax generating private market. Among the side-effects of the rapid change were unclear hierarchy of norms, improvised decision-making based on "best intentions", birth of "open" corruption in place of the blat system, an explosion of new social and economic problems for Russian citizens, and erosion of trust in the new political leaders. 93

Solomon has contended that, in post-socialist Russia, instead of applying the law in a universal manner, officials make and apply rules in the service of particular interests, namely their own, those of their agencies, or those of outside groups. ${ }^{94}$ Salmi has discussed how networks that have continued to be important in the post-socialist reality can be seen as social capital, survival strategies, and legacies of the past. All of these forms can be detected in Salmi's case study of housing allocation in St. Petersburg in 2000. Networks were used as channels of influence on authorities, and the rules of allocation were used strategically to benefit personal networks. ${ }^{95}$

One of the political responses by the Russian leadership to all of this has been the introduction of the term of 'sovereign democracy', which stresses the independence of Russia's own institutional choices. Sakwa sees that Russian leadership's thinking is based on the negation of the 1990s while continuing that era's fundamental projects such as marketization, democratization, and international integration. In the past 10 years, democratization, however, has become increasingly bound up with security concerns; this in turn means that globalized and technocratic modernization of the state has become a primary political goal. ${ }^{96}$ The effects of these security concerns have manifested themselves in the Strategy for National Security and the following Law on Security ${ }^{97}$ that stress the coordination of reforms from the center and modernization of the work of Russian authorities. The effects of administrative stabilization in terms of accountability have differed from sector-to-sector inside the Russian administration in the post-Soviet period. There are also differences in results between regions, cities, and even city districts, as has been shown by an empirical study conducted

Alena V. Ledeneva, "The Subversion of Democracy in Russia”, in Harter and Easter, op.cit. note 86, 320-336; and Brovkin, op.cit. note 48.

Ledeneva, ibid., 325-326.

Brovkin, op.cit. note 13, 215-225.; and Heusala, op.cit. note 1, 235. In the beginning of the 1990s, the relations of local administrative decision-makers and the center were marked by the sudden absence of the Communist Party which had provided a link between the regions and Moscow. The party was gone but the old elite was still in place with its network and power. Gerald Easter, "Institutional Legacy of the Old Regime as a Constraint to Reform: the Case of Fiscal Policy", in Stefanie Harter and Gerald Easter (eds.),Shaping the Economic Space in Russia: Decision Making Processes, Institutions and Adjustments to Change in the El'sin Era (Ashgate, Aldershot, UK, 2000). Here, the writer is describing how the 'shock-therapy' period included drastically reducing government spending, delegating responsibilities to the regional and local levels, and rolling back subsidizing to ineffective state industries. The local level entered market conditions without the financial resources to adapt to the new environment, and the administration at the local level was left with growing social problems and an avalanche of presidential edicts aiming to direct its work while federal legislation was under construction.

Solomon, op.cit. note $85,117$.

Salmi, op.cit. note 59, 210-211.

Richard Sakwa, "Russia's Identity: Between the 'Domestic' and the 'International'”, 63(6) Europe-Asia Studies (2011), 961.

Strategiia natsional'noi bezopasnosti Rossiiskoi Federatsii do 2020 goda (12 May 2009) No.537, Sobranie Zakonodatel'stva Rossiiskoi Federatsii (2009) No.20 item 2444) (hereinafter the "Strategy on National Secutiry"); RF Federal'nyi Zakon "O bezopasnosti” (28 December 2010) No.390-FZ, Rossiiskaia gazeta (19 December 2010) ((hereinafter the "Law on Security"). 
This article has been published in Review of Central and East European Law 38 (2013) 267-293

between 1993 and $2000 .{ }^{98}$ At the level of work organization, public organizations have been able to create a sense of independent administrative collective that, in many cases, is not only able to use its own initiatives and discretion but, also, at least is partially responsible for its own development. One could argue that this type of professionally based growth of local responsibility-based on the Russian tradition of legal positivism - can strengthen the culture of the rule of law in Russian state administration at all three levels of government. Educational reform, access to information and the modernization of technology play no small role in the process.

In the current transformation process, there are two main sources of Russian administrative ideology. The legal mandate for administrative reform is based on the 1993 RF Constitution which underlines the ideals of a welfare (social) state (beginning with Art.7 expressly proclaiming this social-state principle). In state policy-making, Russia's development is linked with the leadership's and civil service's understanding of what the process of globalization ${ }^{99}$ requires from Russia internally. Under the present administrative ideology, this means that the concept of national security covers major aspects of individual social well-being and legitimization for administrative reforms. ${ }^{100}$ Thus, the Russian state has a modernization logic which is a hybrid of rule-of-law ideals, principles of a welfare state, and a security concept ${ }^{101}$ which are the primary sources of state reform. Since the early 1990 s, the international community has paid considerable attention to Russia's integration into European legal structures protecting human rights and freedoms which effects (on the evolution of administrative accountability in our case) are, as yet, unclear. The most important milestone in this regard was the ratification of Convention for the Protection of Human Rights and Fundamental Freedoms (1950) ${ }^{102}$ Kahn has concluded that Russia's acceptance of the jurisdiction of the European Court of Human Rights, indeed, has been very important for the development of the rule of law in Russia, although he warns against focusing only on "law in books" in an attempt to understand the daily realities of courts and police stations for example. The active codification and re-codification that have taken place in the last twenty years and the reform of the criminal-justice system have prepared the necessary foundation for the of strengthening the rule of law. ${ }^{103}$ Important milestones in this regard have been the codifications of the Civil Code, Criminal Code and the Criminal Prosedural Code $^{104}$. Sakwa states that contemporary Russia does not have a systematic alternative to its present government and that it has not been able to provide enduring alternatives to hegemonic Western ideals. ${ }^{105}$ Instead, Russia's 2012 accession to the World Trade Organization continues its integration into the global economic order but presents further demands for administrative and legal modernization.

98 The 2005 published study by Heusala included an empirical section conducted in the local state administration of Murmansk in 1993 and 2000. 36 interviews were conducted in the Administration for Social Protection of the Population, which worked to provide basic social services. These included social assistance to families with children, assigning pensions to retired people, and providing special assistance to the disabled and refugees settling in the area. See Heusala, op.cit. note 1.

99 Robert Legvold, "Encountering Globalization Russian Style", in Julie Wilhemsen and Elana Wilson Rowe (eds.), Russia's Encounter with Globalization: Actors, Processes and Critical Moments (Palgrave MacMillan, Chippenham and Eastbourne, UK, 2011), 15-37.

100 Strategy on National Security, op.cit, note 97; Law on Security, op.cit.note 97.. See, also, Legvold, ibid., 15-37. The national security strategy creates an interesting framework for the assessment of Russian institutional development. The strategy is based on a comprehensive security perspective which includes all sectors of the society. The strategy can be seen as a type of a "welfare state declaration" which is linked to questions of Russia's internal and external security in today's world. Law on Security, ibid.

102 Convention for the Protection of Human Rights and Fundamental Freedoms (1950), reproduced at <http://conventions.coe.int/Treaty/Commun/ListeTraites.asp?CL=ENG\&CM=8>. President Eltsin signed a federal law " O ratifikatsii Konventsii o sashchite prav cheloveka i osnovnyh svobod i Protokolov k nei." Sobranie Zakonodatel'stva, 1998, tom 42, st.1514.

103 Jeffrey Kahn, "Vladimir Putin and the Rule of Law in Russia", 36 Georgia Journal of International and Comparative Law (2008), 511557. Kahn has analyzed at length the reforms of criminal procedure in Russia. In addition to the fact that many of the officials working in the justice and law-enforcement systems still have a Soviet-era education and attitudes, there are new problems related to social inequality in obtaining justice.

104 Ugolovnyi kodeks RF, N 63-F3, 1.1.1997, "Sobranie Zakonodatel’stva RF,N 24, 17 iuniia 1996; Ugolovno-protsessual'nyi kodeks RF, N 174-F3, 18.12.2001, "Sobranie Zakonodatel'stva RF, 24 dekabrja 2001, N 52; Grazhdanskii kodeks RF; chast pervaja, N 51-F3, 1.1.1995, "Sobranie Zakonodatel'stva RF" N 32, 5.dekabrja 1994; chast vtoraja, N 14-F3, 1.4.1996, "Sobranie Zakonodatel'stva RF" N 5, 29 ianvaria 1996; chast tret'ia, N 146-F3, 1.4.2002, "Sobranie Zakonodatel'stva RF" N 49, 3.dekabrja 2001; chast chetvertaia N 203-F3, 1.1.2008, "Sobranie Zakonodatel'stva RF" N 52, 25.dekabrja 2006 
Successful modernization of Russian public administration would necessitate legal protection of individual rights, institutional trust based on the rule of law, and horizontal cooperation among organizations. The current political leadership has adopted the idea that an administrative culture which applies best practices of other societies and global managerial ideas ${ }^{106}$ is critical for the success of Russian reforms. This is addressed by civil service reforms and programs of highereducation institutions. The real effect of new competence-building addressed by the in the modernization of the Russian civil service will be linked to a significant reduction of re-cycled dysfunctions. This necessitates not only attention to the floor-level work-force, but also on the administrative elites composition and transparency of its decision-making practices.

Currently, the security sector is undergoing major attempts ${ }^{107}$ to reform everything from structures to competence of personnel. The complex case of the law-enforcement sector can be viewed as the 'final frontier' in Russia's quest for modern public administration. Law enforcement reflects all other successes and difficulties related to modernization with regard to social, health, education and legal reforms (in books). A 2012 public opinion survey ${ }^{108}$ shows that law and order and the judicial system have a high priority in the list of important questions for Russian citizens. Gel'man has pointed out that formal institutions and the demand for law have served as a "weapon of the weak" in recent years, as people have brought lawsuits against the state. ${ }^{109}$ Hendley has shown that a complicated mixture of need and capacity drives the growing use of the courts in Russia. Societal lack of trust in courts does not prevent citizens or firms from using them. ${ }^{110}$

Unlike in the case of the courts however, mistrust usually does prevent citizens from turning to the police. Three studies deserve attention in this respect. Margarita Zernova's study conducted in 2007 and 2009 in Moscow and a provincial town ${ }^{111}$ showed that trust in law-enforcement institutions is not strong. Citizens describe the use of unofficial coping techniques to avoid reporting crimes to the police. ${ }^{112}$ Occasional assertions of legal rights are atypical in the studied group. Yakov Gilinskiy's report on a study that targeted St. Petersburg, Volgograd, and Borovichi ${ }^{113}$ suggests that the crime rates in these locations were fairly stable between 1999 and 2002, but also that there was a considerable problem of under-reporting to the police. Two-thirds of crime victims failed to report crimes to the police. In St. Petersburg, approximately one-half of the respondents considered the quality of police activity ${ }^{114}$ in their micro-districts to be poor or quite poor. Situations closely related to the rule of law were also negatively viewed. ${ }^{115}$ A more recent study (2011) by Gilinskiy about

106104 Christopher Hood,. "The "New Public Management" in the 1980s: Variations on the Theme", 20 (2/3) Accounting, Organizations and the Society (1995),, 93-109; Aucoin, op.cit., note 14; Barabashev, and Straussman, op.cit, note 7 ;Romanov, op.cit. note 13, 9-53, evaluates the effectiveness of New Public Management in the Russian social services.

107 The most important are the reforms of the Armed Forces and the reform of the Police.

108 PEW Research Center, Global Attitudes Project, "Russians Back Protests, Political Freedoms and Putin, Too" (23 May 2012), available at <http://www.pewglobal.org/files/2012/05/Pew-Global-Attitudes-Project-Russia-Report-FINAL-MAY-23-2012.pdf>.

109 Vladimir Gel'man, "Subversive Institutions, Informal Governance, and Contemporary Russian Politics", 45(3-4) Communist and PostCommunist Studies (2012), 299.

110 Kathryn Hendley, "The Puzzling Non-Consequences of Societal Distrust of Courts: Explaining the Use of Russian Courts", 45(3) Cornell International Law Journal (2012), 557-558.

111 The name of the town is not revealed for reasons of confidentiality.

112 Margarita Zernova, "Coping with the Failure of the Police in Post-Soviet Russia: Findings from One Empirical Study", 6(4) Police Practice and Research: An International Journal (2011). The study was conducted by way of qualitative interviews of 64 people, 10 of whom were police officers. The techniques that citizens used included, among other things, bribing the police, acquiring 'insurance' from the police, pleading and appealing for sympathy, using friendships inside the police, and using influential people outside the police.

113 Yakov Gilinskiy, "Police and the Community in Russia", 6(4) Police Practice and Research: An International Journal (2006), 331-346. This study was conducted as a telephone survey. In 2001, the study comprised 3,500 respondents in St. Petersburg, 2,000 in Volgograd, and 500 in Borovichi. In 2002, the study comprised 7,600 respondents in St. Petersburg. The vast majority (84.7\%-90.6\%) of those who were surveyed were ethnic Russians.

114 Police activity included such issues as success in preserving public order, cooperation with citizens in solving problems of public order, effectiveness of assistance provided by the police to victims of crimes, regulation of police work in crime prevention, maintaining order on the streets and in public places, politeness of police officers, readiness of the police to help the residents of a particular micro-district. Gilinskiy, op.cit. note 102 . More than $40 \%$ of those surveyed considered that taking bribes; unjustified use of physical force against, and brutal treatment of, detained persons; and using insults when detaining a person were serious problems in the police's treatment of residents. Less than $7 \%$ considered these not to be problems at all. About 30\% considered unjustified detention and participation in underground business activity to be serious problems. At the same time, the results showed a slightly different picture with regard to 
This article has been published in Review of Central and East European Law 38 (2013) 267-293

torture by the Russian police tackles a difficult issue at the heart of the rule of law and accountability. The results show that, in particular, detectives and patrol officers have resorted to unlawful and cruel treatment. Gilinskiy concludes that the most critical problem is the indifference of officials and political leaders in tackling this issue. ${ }^{116}$

The 2011 RF Law on the Police ${ }^{117}$ seems to represent an attempt to guide the culture of lawenforcement agencies in the right direction. Yet again, this question is connected to the overall development of the rule of law and an open-access order in Russia which would be reflected in the organizational changes on the local level. It is self-evident that any allegations of unlawful cruelty (or even the widespread belief that such treatment is possible) present serious institutional risks in terms of creating societal trust. A key legal instrument for defining accountability which also has importance in the Police reform, is the 2001 RF Code on Administrative Offenses, ${ }^{118}$ a hybrid piece of legislation containing elements of criminal and administrative law. It states the basic principles of good government and lists prohibited actions (mainly punishable by fines). However, in work cultures such as the police, oral commands from superior officers carry as much weight as official regulations. Furthermore, the riskiness of the work itself and the information with which officials deal make police organizations 'insider cultures'. To change practices and ways of thinking, a long period of readjustment is needed in terms of education systems, student qualifications, training periods, actual recruitment, and quality-assurance systems in the police hierarchy. The 2011 Law on the Police lays the foundation for this work, but a significant amount of long-term commitment is needed to effect changes at different levels of the law-enforcement community. International comparisons of law-enforce reforms and challenges found in them ${ }^{119}$ are essential in this regard.

In assessing the current situation, one should keep in mind that those people most in need of public services tend to be psychologically vulnerable and have poorer resources available to properly fend for themselves. To tackle administrative dysfunctions, the political decision-makers may enforce old-fashioned practices of legalistic decision-making, hierarchical organization and centralization as ways of maintaining law and order. In view of the previous two transitions and the experience gained in the post-perestroika transition, this approach has not led to sufficient reduction of administrative dysfunctions or strengthened societal trust in the long run. Unsatisfactory or bad service resulting from unprofessional behavior, the practice of impunity in cases of legal violations, and the lack of administrative resources or inadequate legislation is more than a question of legality. These features further divide society into different groups of status and privilege, persistent elements of the two previous Russian transitions studied in this work.

\section{Conclusions}

This article has attempted to answer the question of how administrative accountability has evolved in Russia's administrative reforms, with a focus was on legal and administrative changes that have shaped accountability. The author of the present work has introduced the term 'securitization' as a

people who were not victims of crimes but had independent contact with the police. In all of the studied locations, a clear majority of these people (from $56.8 \%$ to $88 \%$ ) thought that the police had been attentive to their problems, rather fair or completely fair and had given them real help, although not sufficiently. The only consistently negative aspect was the impoliteness of the police officers.

Yakov Gilinskiy, "Torture by the Russian Police: An Empirical Study", 12(2) Police Practice and Research: An International Journal (2011), 163-171. In this study, 5,565 people were surveyed in St. Petersburg, Pskov, Nizhny Novgorod, Komi, and Chita. The alleged motives for torture identified by respondents were most commonly humiliation, amusement, extortion (for money or belongings), and coercion to get detainees to incriminate themselves. The 35 experts who were interviewed (in addition to the survey) stated that the most important reason for the use of torture was the low level of proficiency of the personnel in law-enforcement agencies, their unsuitable mentality, their lack of professionalism, and impunity.

117 RF Federal'nyi Zakon “O politsii” (7 February 2011) No. 3-FZ, Rossiiskaia gazeta (8 February 2011) No.5401 (hereinafter the "Law on Police").

118 RF Federal'nyi Zakon, Kodeks Rossiiskoi Federatsii “Ob administrativnykh pravonarusheniiakh” (30 December 2001) No.195-FZ, Rossiiskaia gazeta (31 December 2001) No.256.

119 Peter Kratcoski, "International Perspectives on Institutional and Police Corruption", 3(1) Police Practice and Research: An International Journal (2002), 73-78; Allan Y, Jiao and Harry M.Rhea, 'Integration of Police in the United States: Changes and Development after 9/11', 17 (4) Policing and Society (2007), 388 - 408; Dermot P. J. Walsh and Vicky Conway, "Police governance and accountability: overview of current issues", 55 Crime Law Soc Change (2011),61-86; Alan Doig and;Michael Levi, "Inter-agency work and the UK public sector investigation of fraud, 1996-2006: joined-up rhetoric and disjointed reality”, 19 (3) Policing and Society (2009), $199-215$, 
This article has been published in Review of Central and East European Law 38 (2013) 267-293

conceptual tool to understand situations where actions taken to address security concerns start to counterbalance reform goals. Security concerns refer to serious institutional risks, such as corruption, which compromise public trust in government and make guidance of administrative decision-making difficult. The 'securitization' of the administrative and legal goals of change has been a recurring phenomenon in Russian history, having taken over reform processes in the studied transitions with different intensities throughout that history. A review of existing historical research suggests that 'securitization' has been a result of complicated state-citizen relations and a reaction to incoherent administrative practices. In all the studies transition periods, restricted political competition and authoritarian features of government have contributed to the difficulties of changing administrative rules and practices, and because of this unofficial practices, such as corruption, have often been used to circumvent official structures. As a reaction to security concerns, the central government has typically used centralization and the intensification of rules in all the studied transition periods. The law has been an important tool in 'securitization' which has had significant consequences for its use in administrative decision-making. The post-perestroika state administration is trying to balance between implementation of stricter policy rules and adaption to other reform goals. In spite of centralization, new actors have continued to recycle corrupt ways of gaining power. In all the three transitions, the institutionalization of new professional practices and ways of thinking has been difficult, and the Russian administrative leadership has in fact remained diffuse outside of the highest political power. In the post-1993 era the emphasis is still placed on organizational hierarchy and the legalistic application of rules. Trust remains personal, and horizontal operative cooperation among administrative organizations has developed slowly after the turbulent years of the 1990s. ${ }^{120}$

Ongoing public-sector reforms in Russia are strategically guided by national-security goals. ${ }^{121}$ Many administrative reforms also find legitimacy in the 1993 Constitution, which defines Russia as a welfare state. In the current phase of Russia's transformation, political stability has been underlined as essential for supporting reformist policies. ${ }^{122}$ Yet, factors connected with unsatisfactory administrative performance and statewide corruption in the post-perestroika era are lowering public trust in both the reforms and the political choices of the leadership. In the current situation, political centralization and corruption define - to a significant extent - the image of Russian public-sector accountability. Federal-level corruption is seen as an obstacle to any serious reform and a reason for growing public dissatisfaction. Unsatisfactory performance on the part of the public administration is further accelerating social divisions in Russian society. While the development of new accountability in the Russian public administration is as yet unresolved, it is a question that - to a great degree — will define Russia's future. 